\title{
Terminal Heat Stress and its Effects in Wheat Crop: A Review
}

\author{
Pimardeep Kaur* \\ Sant Farid School Malwal Road, Ferozepur City \\ *Corresponding author
}

\section{A B S T R A C T}

\begin{tabular}{l} 
Ke y w o r d s \\
Heat Stress, \\
Physiological \\
Parameters, Grain \\
Yield, Chlorophyll \\
Content, Canopy \\
Temperature \\
\hline Article Info \\
\hline $\begin{array}{l}\text { Accepted: } \\
\text { 12 December } 2020 \\
\text { Available Online: } \\
\text { 10 January 2021 }\end{array}$ \\
\hline
\end{tabular}

\section{Introduction}

Wheat (Triticum aestivum) is a cool season crop, but its cultivation extends well beyond its typical adaptation zone. In India alone, about 13.5 million ha of wheat crop (about half of the total acreage) is estimated to be heat stressed (Joshi et al 2007). With the current trends of climate change, the heat stressed wheat production environments around the world are apprehended to increase about three fold by 2050 (Trethowan et al 2005). Wheat represents world's maximum cereal area with over 220 million ha cultivated worldwide which is often heat stressed. Heat stress (HS) can impair wheat growth at any developmental stage and in the future scenarios predict even warmer temperatures (Easterling and Apps 2005).

Plants detect changes in ambient temperature through per turbations in metabolism, membrane fluidity, protein conformation and assembly of the cytoskeleton (Ruelland and Zachowski 2010). Heat shock proteins are expressed by such reactions until new cellular equilibriums are reached. However, temperatures above the optimum for growth can be deleterious, causing injury or irreversible damage, which is generally called 'heat stress' (Wahid et al 2007). Heat stress is a function of rate of temperature increase and 
the magnitude and the duration of exposure to the raised temperature as well (Wahid et al 2007). Heat stress causes damage to various cellular components, so it is obvious that in order to survive a large number of different protective pathways are required. Induction of any one of these pathways makes the plant thermotolerant to some extent and the loss of any specific pathway merely limits that tolerance (Larkindale et al 2005).

Wheat is very sensitive to high temperature and increasing growing season temperatures trends have already been reported for the major wheat-producing areas (Alexander et al 2006, Hennessy et al 2008). Wheat experiences heat stress at different phenological stages, but during the reproductive phase heat stress is more harmful than during the vegetative phase due to the direct effect on grain number and dry weight (Wollenweber et al., 2003). Hence the main focus is on responses to elevated temperatures during reproductive and grainfilling stages and processes that affect grain yield.

Heat-tolerant cultivars' development is concerned majorly in wheat breeding programs. An understanding of the genetics and physiology of heat tolerance in detail as well as the use of the proper germplasm and selection methods will lead the development of heat tolerant cultivars of wheat (Fokar et al 1998b). Heat tolerance is not controlled by a single gene in cereals. Different components of tolerance determined by different sets of genes are critical for heat tolerance at different stages of the life cycle and in various tissues (Maestri et al 2002). Yield potential of any variety is the combined effect of genotypes and environmental interaction. Nowadays, due to global warming, climatic conditions are changing and temperature begins to rise in late February and March coupled with hot dry winds during the post anthesis stages, especially during grain development terminate grain growth prematurely and reduces yield considerably. Hence, there is need to breed new genotypes having genetic mechanism to tolerate high temperature by involving novel genes from diverse parents to sustain and maximize productivity of wheat under warmer areas of India.

Under high temperature (HT) stress, plant can survive with the ability to perceive the HT stimulus, generate and transmit the signal and initiate appropriate physiological and biochemical changes. Tolerance is improved substantially by HT-induced gene expression and metabolite synthesis. Hence, Current research areas are the physiological and biochemical responses to heat stress and the molecular approaches are adopted to develop HT tolerance in plants. The present article reviews the various findings on response and tolerance to HT at the cellular, organelle and whole plant levels.

\section{Heat stress}

Multidisciplinary research involving genetic resources enhancement and crop physiology at CIMMYT have led to a physiological trait based approach to breeding for abiotic stress which has merit over breeding for yield per se by increasing the probability of successful crosses resulting from additive gene action. Advances have already been made in the drought-breeding program (Reynolds and Borlaug 2006, Ortiz et al 2007) and this strategy will be used to breed wheat for the high temperature stressed Environments. A limiting factor in wheat production in many countries is the occurrence of temperature stress at grain filling stage especially in West Asia and North Africa. In another study by Singh et al (2001), it was found that for every $1^{\circ} \mathrm{C}$ increase in mean temperature above normal, grain yield was reduced by $12-23 \%$. 
Pollen sterility, tissue dehydration, lower $\mathrm{CO}_{2}$ assimilation and increased photorespiration can be caused by heat stress during the reproductive phase. Though growth is accelerated by high temperatures, the phenology is also reduced, which is not compensated for by the increased growth rate (Zahedi and Jenner 2003). During reproductive and grain-filling phases, water is required for stem and peduncle elongation to raise the ear up through the unfolding leaf to the top of the canopy and growth of all parts of the ear, pollen ripening, rapid extension of stamen filaments and fertilization, grain growth and filling. Water flow for these processes involves crossing membranes, possibly facilitated by aquaporins. High temperature tends to increase hydraulic conductivity of membranes and plant tissues due to increase in aquaporin activity, membrane fluidity and permeability (Martinez- Ballesta 2009) and reduced water viscosity to a greater drgree (Cochard et al 2007).

Nawaz et al (2013) found that heat stress negatively influences the chlorophyll and grain filling processes in plants. Heat stress drastically reduces the performance of all wheat cultivars at all stages; severity being at booting and heading stages than anthesis and grain filling stages. Heat stress is more harmful when it occurs at reproductive and grain filling stages (Hays et al 2007, Farooq et al 2011).

Heat stress affects photosynthetic capacity of plants, promotes the production of oxidative reactive species (Wang et al 2011), reduces pollen tube development and causes pollen mortality (Saini et al 2010), improves ethylene production thus increasing grain abortion (Hays et al 2007) and also causes oxidative damage to the chloroplast which results in minimum grain yield (Farooq et al 2011).
Heat stress also interrupts the grain filling in plants through reduction in grain weight and grain number (Wollenweber et al 2003, Schapendonk et al 2007), resulting in less grain yield (Mullarkey and Jones 2000, Tewolde et al 2006). For example, increase of just $1^{\circ} \mathrm{C}$ temperature above $15-20^{\circ} \mathrm{C}$ at grain filling stage can reduce grain weight by 1.5 mg per day (Streck 2005).

\section{Effects of Heat Stress}

\section{Physiological parameters}

Early maturing genotypes have the ability to possess greater grain weight and longer grain formation period thereby having the ability to tolerate heat stress as compared to long duration genotypes (Singh et al 2005). Some of the studies in late conditions revealed that days to heading, days to maturity, plant height, number of tillers per plant, spikelets per spike, 1000 grain weight, grain yield per plant, biomass per plant and harvest index were under the control of additive genetic effects and direct selection methodologies can be adopted in the selection of these traits (Chandrashekhar and Kerketta 2004). Comparison of mean of two sowing extremes revealed that plant height, days to heading, days to maturity, spikelets per spike, grains per spike and grain yield are greatly reduced as a result of different sowing times (Mahboob et al 2005). Similarly the yield is greatly reduced due to late sowing as reported by Arain et al (2002). M Qasim et al (2008) reported that the plant height decreased progressively with each delayed sowing. The earlier sown crop had longer vegetative growth period than late sown crop which resulted in more plant height.

\section{Canopy temperature}

Amani et al (1996) also used canopy temperature depression (CTD) to select for 
yield under a hot, dry, irrigated wheat environment in Mexico. It had been pronounced that CTD is usually expressed as canopy temperature $(\mathrm{Tc})$ minus air temperature (Ta) and it is positive when the canopy is cooler than the air. It has been used as a selection criterion in wheat breeding in terms of heat and drought stress tolerance (Reynolds et al 2001, Balota et al 2007). According to Munjal and Rana (2003) at grain filling period, cooler canopy and high stomatal conductance are assumed as the basic morpho-physiological criteria for higher grain yield under heat stressed conditions. Under more optimum (irrigated) conditions overall CTD showed relative high correlation with yield (Ginkel et al 2004). It is also recommended that CTD could be used to identify plants with cooler canopies with the aim of yield increasing under non-stressed conditions. The correlation study (Kumari et al 2012) showed that leaf area under greenness (LAUG) and canopy temperature depression (CTD) were strongly correlated. LAUG and CTD were also significantly associated with grain yield and biomass.

\section{Photosynthetic Rate and Chlorophyll Content}

Studies at CIMMYT demonstrated that under heat-stressed field conditions, photosynthetic rate has genetic variability (Delgado et al 1994). Physiological evidence indicates that loss of chlorophyll during grain filling is associated with reduced grain yield (Reynolds et al 1994). Wardlaw et al (1980) and Blum (1986) also revealed that in controlled environments, photosynthetic rate is genetically variable among wheat cultivars when exposed to high temperatures. Under heat stress, such differences in photosynthesis associated with a loss of chlorophyll and change in a:b chlorophyll ratio due to premature leaf senescence (Al-Khatib and Paulsen 1984, Harding et al 1990). Dhyani et al (2013) observed that heat stress affects chlorophyll content and leaf area index (LAI) dramatically in sensitive genotypes under late sown conditions. At high temperature stress under late planting condition those genotypes are considered as heat tolerant that retain normal flag leaf chlorophyll for a longer period (Gupta et al 2006) and useful component for evaluating the tolerance of a crop to high temperature is proline which accumulates in plants under supra optimal temperature (Chaitanya et al 2001). When plants were stressed during vegetative and reproductive phases whole plant photosynthetic rates decline rapidly (Gupta $e t$ al 2006). Hasan et al (2007) reported that chlorophyll contents decreased with late sowing in all wheat genotypes.

\section{Stem reserves}

Important source of carbon for grain filling is stem reserves from pre-anthesis plant assimilation when current photosynthesis is inhibited by drought, heat or disease stress during this stage. The percentage of stem reserves in total grain mass or stem reserve mobilization is affected by sink size, cultivar and the environment. The relative study (in heat stress condition compared to normal condition) by Roy et al (2013) indicated that the heat tolerant genotypes had greater ability to utilize stem reserve compared to heat sensitive genotypes. Few studies suggested that the high capacity to utilize stem reserves for grain filling might be linked with accelerated leaf senescence (Yang et al 2000). Tahir and Nakata (2005) studied the dynamics of stored total nonstructural carbohydrates and nitrogen in leaves and stems under heat stress conditions.

These results suggest that rate of chlorophyll loss from flag leaf is positively correlated with nitrogen and total nonstructural carbohydrates remobilization efficiencies 
under heat stress, suggesting a strong link between leaf senescence and remobilization efficiency.

\section{Stay green}

Stay Green genotypes retain chlorophyll in their leaves and the photosynthesis is carried for longer than the senescent types and are often shown to have a yield benefit (Borell et al 2001, Jordan et al 2003). Harris et al (2007) suggested three important components of tolerance were the SPAD reading at anthesis, the duration of senescence and rate of senescence. They suggest that important component of stay-green is rate of senescence rather than onset of senescence. Kumar et al (2010) have reported that stay green or delayed senescence is considered to play a crucial role in grain development in wheat when assimilates are limited, and stay green cultivars are well adapted to drought and heat stressed conditions. Nawaz et al (2013) reported that in heat sensitive cultivars, the imposition of heat increased the grain filling rate with a substantial decrease in grain filling duration. Thus, selection criteria for developing new wheat cultivars for heat resistance during reproductive stages would be stay green character and grain filling rate and duration under heat stress.

\section{Yield related parameters}

\section{Number of Tillers}

Tillering can be described as the degree of branching that determines the number of spikes per unit area, an important yield component, influencing light interception by the canopy and likely associated water use (Duggan et al 2005). To extent that high tiller number contributes to early season ground cover, this trait assists in competing against weeds and minimizing water loss due to soil evaporation in Mediterranean climates
(Borras-Gelonch et al 2010). Tahir et al (2009) reported that less number of tillers in late sowing was the result of less germination count per unit area which occurs due to low temperature. In case of delayed sowing the temperature was not according to the tillering requirement which results in less number of tillers per meter square. Differences in number of tillers per meter square among varieties might be attributed to their genetic diversity.

\section{Number of Spikelets}

Reduction in spike number per meter square is mainly due to higher tiller production in early sowing date with cooler temperatures during vegetative phase and decreasing in duration of vegetative phase in late sowing dates due to higher temperatures. This effect of sowing date on spike number per $\mathrm{m}^{2}$ has also been reported by Ayeneh et al (2002). Rahman et al (2009) reported that green leaf area and productive tillers per plant were drastically reduced under high temperature (30/25 ${ }^{\circ}$, day/night).

Due to late sowing-induced heat stress, the spike length, number of spikelets per spike, number of tiller per meter row length were reduced significantly which further resulted in reduced grain yield (Ahamed et al 2010). Modaressi et al (2010) reported that high temperature could decrease grain yield upto $46.63 \%$, 1000-grain weight, grain filling period upto $20 \%$ and spikelets per spike was reduced to $11 \%$.

\section{Grain Shrinkage}

Elevated temperatures can also cause grain shrinkage through ultrastructural changes in the aleurone layer and endosperm cells as observed by Dias et al (2008) when day/night temperatures increased from $25 / 14^{\circ} \mathrm{C}$ to $31 / 20^{\circ} \mathrm{C}$. As temperatures rise above 18 - 
$22^{\circ} \mathrm{C}$, the duration of starch biosynthesis and deposition to grain is reduced (Spiertz et al 2006). Heat stress accelerates the rate of grain filling whereas grain filling duration is shortened (Dias and Lidon 2009). For instance, $5^{\circ} \mathrm{C}$ increase in temperature above $20^{\circ} \mathrm{C}$ increased the rate of grain filling and reduced the grain filling duration by 12 days in wheat (Yin et al 2009). Under these conditions, the supply of photoassimilates may be limited (Calderini et al 2006).

Sarkar C K Guha et al (2001) noticed that the susceptible genotypes possessed relatively high grains number per spike as compared to tolerant types, while the 1000-grain weight was relatively high in the tolerant ones. High 1000-grain weight obtained in most of the tolerant types was likely because they could maintain high Grain Growth Rates (GGRs) under high temperature stress condition. Mian et al (2007) also observed that delayed sowing shortens the duration of each development phase which ultimately reduces grain filling period and lowers the grain weight. Decreasing in thousand grain weight with delay in sowing date is also due to high temperatures in March, April and May when temperatures raised and terminal heat stress coincided with grain filling period.

Grain development is impacted by heat stress because assimilate translocation and grainfilling duration and rate are influenced directly by changes in ambient temperature. The extent of heat-driven damage is dependent on the level of heat stress. Reduced number of ears per $\mathrm{m}^{2}$, number of grains per ear and reduced grain size were the major responsible factors for reducing the grain yield under heat stress condition. Results from other studies showed that late planting heat stress caused lower grain yield in wheat compared to optimum sowing (Kosina et al 2007, Rehman et al 2009).

\section{Reproductive Phase}

Rane et al (2007) reported that decrease in duration of crop life cycle with delay in sowing date and coincidence of terminal heat stress in grain filling period caused lower biological yield. Minimum grain yield in wheat genotypes due to heat stress at reproductive stages may be due to least duration for resource utilization during grain filling (Dias and Lidon 2009, Yin et al 2009). Heat stress modifies the early dough and maturity stage, shorten the kernel dessication period and cause grain yield loss in wheat (Zhang et al 2013). Post-anthesis heat stress in wheat induces several physiological effects which eventually result in smaller grain size due to reduced grain filling period and reduced grain filling rate or the combined effect of both (Hasan and Ahmed 2005). Choosing a suitable planting date and genotype with the appropriate phenology that matches crop growth to the climate conditions will lead to optimum grain yields (Chen et al 2003).

In conclusion with the current trends of climate change, the heat stressed wheat production environments around the world are apprehended to increase about three fold by 2050. Heat stress is a function of the magnitude and rate of temperature increase, as well as the duration of exposure to the raised temperature. Wheat experiences heat stress to varying degrees at different phenological stages, but heat stress during the reproductive phase is more harmful than during the vegetative phase due to the direct effect on grain number and dry weight.

It may be concluded that grain yield is an important selection criterion for breeding programmes. Grain yield is related with various traits such as morphological, physiological and yield components. These yield related traits like number of tillers per 
plant, plant height, flag leaf area, and spike characteristics like spike length, spike density, spikelets per spike, 100-grain weight and grain yield per plant etc. under both conditions play important role to improve yield stability and potential. These plant traits may contribute towards high grain yield and can help the plant to perform well in normal and stress conditions. The information obtained from these traits may be used to evolve high yielding varieties which can produce economic yield and help the yield sustainability in those areas where terminal heat stress is a major threat.

\section{References}

Ahamed K U, Nahar K, Fujita $M$ and Hasanuzzaman M (2010) Variation in plant growth, tiller dynamics and yield components of wheat (Triticum aestivum L.) due to high temperature stress. Adv Agric Bot 2: 213-24.

Alexander L V, Zhang X, Peterson T C, Caesar J, Gleason B, Tank A, Haylock M, Collins D, Trewin B, Rahimzadeh F, Tagipour A, Kumar K R, Revadekar J, Griffiths G, Vincent L, Stephenson D B, Burn J, Aguilar E, Brunet M, Taylor M, New M, Zhai P, Rusticucci $M$ and Vazquez-Aguirre $J$ L (2006) Global observed changes in daily climate extremes of temperature and precipitation. J Geophys Res Atmos 111: 122.

Al-Khatib K and Paulsen G M (1984) Mode of high temperature injury to wheat during grain development. Plant Physiol 61: 363-68.

Amani I, Fischer R A and Reynolds M P (1996) Canopy temperature depression associated with yield of irrigated spring wheat cultivars in a hot climate. J Agron Crop Sci 176: 11929.

Arain M A, Sial M A and Javed M A (2002) Influence of different seeding rates and row spacings on yield contributing traits in wheat. Pak J Seed Tech 1: 1-6.

Ayeneh A, Van-Ginkel M, Reynolds M P and Amma K (2002) Comparison of leaf, spike, peduncle and canopy temperature depression in wheat under heat stress. Field Crops Res
79: 173-84.

Balota M, Payne W A, Evet S R and Lazar M D (2007) Canopy temperature depression sampling to assess grain yield and genotypic differentiation in winter wheat. Crop Sci 47: 1518-29.

Blum A (1986) The effect of heat stress on wheat leaf and ear photosynthesis. J Exp Bot 37: 111-18.

Borras-Gelonch G, Slafer G A, Casas A M, van Eeuwijk F and Romagosa I (2010) Genetic control of pre-heading phases and other traits related to development in a double-haploid barley (Hordeum vulgare L.) population. Field Crop Res 119: 36-47.

Borrell A K, Hammer G and van Oosterom E (2001) Stay-green: A consequence of the balance between supply and demand for nitrogen during grain filling. Ann Appl Biol 138: 91-95.

Calderini D F, Reynolds M P and Slafer G A (2006) Source-sink effects on grain weight of bread wheat, durum wheat and triticale at different locations. Aust J Agric Res 57: 22733.

Chaitanya K V, Sundar D and Reddy A R (2001) Mulberry leaf metabolism under high temperature stress. Biol Plants 44: 379-84.

Chandrashekhar M and Kerketta V (2004) Estimation of some genetic parameters under normal and late sown conditions in wheat (Triticum aestivum L). J Res Bisra Agri Uni 16: 119-21.

Chen C, Payne W A, Smiley R W and Stoltz M A (2003) Yield and water-use efficiency of eight wheat cultivars planted on seven dates in northeastern Oregon. Agro J 95: 836-43.

Cochard H, Venisse J S, Barigah T S, Brunel N, Herbette S, Guilliot A, Tyree M T and Sakr S (2007) Putative role of aquaporins in variable hydraulic conductance of leaves in response to light. Plant Physiol 143: 122-33.

Delgado B M I, Reynolds M P, Larque-Saavedra A and Nava T S (1994) Genetic diversity for photosynthesis in wheat under heat stressed environments and its relationship to productivity. Wheat Special Report No. 30. Mexico DF CIMMYT.

Dhyani K, Ansari M W, Rao Y R, Verma R S, Shukla A and Tuteja N (2013) Comparitive physiological response of wheat genotypes 
under terminal heat stress. Plant Signal Behav 8: $1-6$.

Dias A S and Lidon F C (2009) Evaluation of grain filling rate and duration in bread and durum wheat, under heat stress after anthesis. J Agron Crop Sci 195: 137-47.

Dias A S, Bagulho A S and Lidon F C (2008) Ultrastructure and biochemical traits of bread and durum wheat grains under heat stress. Brazz J Plant Physiol 20: 323-33.

Duggan B L, Richards R A and van Herwaarden A F (2005) Agronomic evaluation of a tiller inhibition gene (tin) in wheat. II. Growth and partitioning of assimilate. Aust J Agr Res 56: 179-86.

Easterling D R and Apps M (2005) Assessing the consequences of climate change for food and forest resources: a view from the IPCC. Clim Change 70: 165-89.

Farooq M, Bramley H, Palta J A and Siddique K H M (2011) Heat stress in wheat during reproductive and grain filling phases. Crit Rev Plant Sci 30: 1-17.

Fokar M, Blum A and Nguyen H T (1998b) Heat tolerance in spring wheat. II. Grain filling. Euphytica 104: 9-15.

Ginkel M, Reynolds M P, Trethowan R and Hernandez E (2004) Can canopy temperature depression measurements help breeders in selecting for yield in wheat under irrigated production conditions? In: Proc 4th International Crop Science Congr. Brisbane, Australia.

Gupta N K, Gupta S, Shukla D S and Deshmukh P S (2006) Post anthesis high temperature influences photosynthesis, grain growth and dry matter accumulation in contrasting wheat genotypes. Physiol Mole Bio Plants 12: 15156.

Harding S A, Guikema J A and Paulsen G M (1990) Photosynthetic decline from high temperature stress during maturation of wheat. II Interaction with source and sink processes. Plant Physiol 92: 654-58.

Harris K, Subudhi P K, Borrell A, Jordan D, Rosenow D, Nguyen H T, Klein P, Klein R and Mullet J (2007) Sorghum stay-green QTL individually reduce post-flowering droughtinduced leaf senescence. J Exp Bot 58: 32738.

Hasan M A and Ahmad J U (2005) Kernel growth physiology of wheat under late planting heat stress. J Natl Sci Found 33: 193-204.

Hasan M A, Ahmed J U, Bahadur M M, Haque M $M$ and Sikder S (2007) Effect of late planting heat stress on membrane thermostability, proline content and heat susceptibility index of different wheat cultivars. J Natl Sci Found 35: 109-17.

Hays D B, Do J H, Mason R E, Morgan G and Finlayson S A (2007) Heat stress induced ethylene production in developing wheat grains induces kernel abortion and increased maturation in a susceptible cultivar. Plant Sci 172: 1113-23.

Hennessy K, Fawcett R, Kirono D, Mpelasoka F, Jones D, Bathols J, Whetton P, Stafford S M, Howden M, Mitcell C and Plummer N (2008) An assessment of the impact of climate change on the nature and frequency of exceptional climatic events. CSIRO and Bureau of Meteorology.

Jordan D R, Tao Y, Godwin I D, Henzell R G, Cooper M and McIntyre C L (2003) Prediction of hybrid performance in grain sorghum using RFLP markers. Theor Appl Genet 106: 559-67.

Joshi A K, Mishra B, Chatrath R, Ferrara G O and Ravi P S (2007) Wheat improvement in India, present status, emerging challenges and future prospects. Euphytica 157: 431-46.

Kosina P, Reynolds M P, Dixon J and Joshi A (2007) Stakeholder perception of wheat production constraints, capacity building needs and research partnerships in the developing countries. Euphytica 157: 475-83.

Kumar U, Joshi A K, Kumari M, Paliwal R, Kumar S and Roder M S (2010) Identification of QTLs for stay green trait in wheat (Triticum aestivum L.) in the 'Chirya 3 ' $\times$ 'Sonalika' population. Euphytica 174: 43745.

Kumari M, Pudake R N, Singh V P and Joshi A K (2012) Association of staygreen trait with canopy temperature depression and yield traits under terminal heat stress in wheat (Triticum aestivum L.). Euphytica 190: 8797.

Larkindale J, Hall J D, Knight M R and Vierling E (2005) Heat stress phenotypes of Arabidopsis mutants implicate multiple signaling pathways in the acquisition of 
thermotolerance. Plant Physiol 138: 882-97.

Maestri E, Klueva N, Perrotta C, Gulli M, Nguyen H T and Mamiroli N (2002) Molecular genetics of heat tolerance and heat shock proteins in cereals. Plant Mol Biol 48: 66781.

Mahboob A S, Arain M A, Khanzada S, Naqvi M A, Dahot M U and Nizami N A (2005) Yield and quality parameters of wheat genotypes as affected by sowing date and temperature stress. Pak J Bot 37: 575-84.

Martinez-Ballesta M C, Lopez-Perez L, Muries B, Munoz-Azcarate O and Carvajal M (2009) Climate change and plant water balance: the role of aquaporins- a review. In: Lichtfouse E (ed) Climate Change, Intercropping, Pest Control and Beneficial Microorganisms. Pp 71-89. Springer, Netherlands.

Mian M A, Mahmood A, Ihsan M and Cheema N M (2007) Response of different wheat cultivars to post anthesis temperature stress. $J$ Agri Res 45: 269-77.

Modarresi M, Mohammdi V, Zali A and Mardi M (2010) Response of wheat yield and yield related traits of high temperature. Cereal Res Commun 38: 25-31.

Mullarkey M and Jones P (2000) Isolation and analysis of thermotolerant mutants of wheat. $J$ Exp Bot 51: 139-46.

Munjal R and Rana R K (2003) Evaluation of physiological traits in wheat (Triticum aestivum L.) for terminal high temperature tolerance. In: Proc 10th International Wheat Genetics Symp, Vol 2, pp 804-05. Classical and Molecular Breeding, Poestum, Italy.

Nawaz A, Farooq M, Cheema S A and Wahid A (2013) Differential response of wheat cultivars to terminal heat stress. Int J Agric Biol 15: 1354-58.

Nawaz A, Farooq M, Cheema S A and Wahid A (2013) Differential response of wheat cultivars to terminal heat stress. Int J Agric Biol 15: 1354-58.

Ortiz R, Trethowan R, Ortiz Ferrara G F, Iwanaga M, Dodds J H, Crouch J H, Crossa J and Braun H J (2007) High yield potential, shuttle breeding, genetic diversity and new international wheat improvement strategy. Euphytica 157: 365-84.

Qasim M, Qamer M, Faridullah and Alam M (2008) Sowing dates effect on yield and yield components of different wheat varieties. $J$ Agric Res 46: 135-40.

Rahman M A, Chikushi J, Yoshida S and Karim A J M S (2009) Growth and yield components of wheat genotypes exposed to high temperature stress under control environment. Bangladesh J Agric Res 34: 361-72.

Rane J, Pannu R K, Sohu V S, Saini R S, Mishra B, Shoran J, Crossa J, Vargas M and Joshi K (2007) Performance of yield and stability of advanced wheat cultivar under heat stress environments of the indo-gangetic plains. Crop Sci 47: 1561-72.

Rehman A U, Habib I, Ahmad N, Hussain M, Khan M A, Farooq J and Ali M A (2009) Screening wheat germplasm for heat tolerance at terminal growth stage. Plant Omics J 2: 09-19.

Reynolds M P and Borlaug N E (2006) Impacts of breeding on international collaborative wheat improvement. J Agric Sci Cambridge 144: 318.

Reynolds M P, Balota M, Delgado M I B, Amani I and Fisher R A (1994) Physiological and morphological traits associated with spring wheat yield under hot irrigated conditions. Aus J Plant Physiol 21: 717-30.

Reynolds M P, Nagarajan S, Razzaque M A and Ageeb O A A (2001) Heat tolerance. In: Reynolds M P, Ortiz Monasterio J I and Mc Nab A (ed) Application of Physiology in Wheat Breeding. Pp 124-35. CIMMYT, Mexico, DF.

Roy T K, Hafiz M H R, Islam M R, Hasan M A and Siddiqui M N (2013) Late planting heat stress on ear growth physiology of wheat. Int J Biosci 3: 8-13.

Ruelland E and Zachowski A (2010) How plants sense temperature. Environ Exper Bot 69: 225-32.

Saini H S, Sedgley M and Aspinall D (2010) Effect of heat stress during floral development on pollen tube growth and ovary anatomy in wheat (Triticum aestivum L.) Aust J Plant Plant Physiol 10: 137-44.

Sarkar C K Guha, Srivastava P S L and Deshmukh P S (2001) Grain growth rate and heat susceptibility index: Traits for breeding genotypes tolerant to terminal high temperature stress in bread wheat (Triticum 
aestivum L). Indian J Genet 61: 209-12.

Schapendonk A H C M, Xu H Y, Putten P E L V D and Spiertz J H J (2007) Heat-shock effects on photosynthesis and sink-source dynamics in wheat (Triticum aestivum L.). NJAS-Wageningen J Life Sci 55: 37-54.

Singh S, Jain M C and Singh J P (2001) Growth and yield response of wheat cultivars to hyperthermal stress. Indian J Plant Physiol 6: 395-402.

Spiertz J H J, Hamer R J, Xu H, Primo-Martin C, Don C and van der Putten P E L (2006) Heat stress in wheat (Triticum aestivum L.): Effects on grain growth and quality traits. Eur J Agron 25: 89-95.

Streck N A (2005) Climate change and agroecosysytems: the effect of elevated atmospheric $\mathrm{CO}_{2}$ and temperature on crop growth, development and yield. Ciencia Rural 35: 730-40.

Tahir I S A and Nakata N (2005) Remobilization of nitrogen and carbohydrate from stems of between supply and demand for nitrogen during grain filling. Ann Appl Biol 138: 9195.

Tahir M, Ali A, Nadir M A, Hussain A and Khalid F (2009) Effect of different sowing dates on growth and yield wheat (Triticum aestivum L.) varieties in district Jhang, Pakistan. Pak J life Soc Sci 7: 66-69.

Tewolde H, Fernandez C J and Erickson C A (2006) Wheat cultivars adapted to postheading high temperature stress. J Agron Crop Sci 192: 111-20.

Trethowan R M, Hodson D, Braun H J, Pfeiffer W $\mathrm{H}$ (2005) Wheat breeding environments, 1988-2002. In: Dubin J, Lantican M A, Morris M L (ed) Impacts of international wheat breeding research in the developing world. Pp 4-11. CIMMYT, Mexico, DF.

Wahid A, Gelani S, Ashraf M and Foolad M R
(2007) Heat tolerance in plants: An overview. Environ Exp Bot 61: 199-223.

Wang X, Cai J, Jiang D Liu F, Dai T and Cao W (2011) Pre-anthesis high-temperature acclimation alleviates damage to the flag leaf caused by post-anthesis heat stress in wheat. $J$ Plant Physiol 168: 585-93.

Wardlaw I F, Sofield I and Cartwright P M (1980) Factors limiting the rate of dry matter accumulation in the grain of wheat grown at high temperatures. Aus J Plant Physiol 40: $15-24$.

Wollenweber B, Porter J R and Schellberg J (2003) Lack of interaction between extreme high-temperature events at vegetative and reproductive growth stages in wheat. J Agron Crop Sci 189: 142-50.

Yang J, Zhang J, Huang X, Zu Q and Wang L (2000) Remobilization of carbon reserves is improved by controlled soil-drying during grain filling in wheat. Crop Sci. 40: 1645-55.

Yin X, Guo W and Spiertz J H (2009) Aquantitative approach to characterize sinksource relationships during grain filling in contrasting wheat genotypes. Field Crops Res 114: 119-26.

Zahedi M and Jenner C F (2003) Analysis of effects in wheat of high temperature on grain filling attributes estimated from mathematical models of grain filling. J Agric Sci 141: 20312.

Zhang X, Cai J, Wollenweber B, Liu F, Dai T, Cao W and Jiang D (2013) Multiple heat and drought events affect grain yield and accumulations of high molecular weight glutenin subunits and glutenin macropolymers in wheat. J Cereal Sci 57: $134-40$.

\section{How to cite this article:}

Pimardeep Kaur. 2021. Terminal Heat Stress and its Effects in Wheat Crop: A Review. Int.J.Curr.Microbiol.App.Sci. 10(01): 1678-1687. doi: https://doi.org/10.20546/ijcmas.2021.1001.196 